\title{
Power generation alternatives from biomass gasification using different syngas pathways
}

\author{
F. Campuzano ${ }^{1}$, C. Arenas ${ }^{1}$, M. Betancur ${ }^{1}$, A. Hill $^{2}$ \& J. D. Martínez ${ }^{1}$ \\ ${ }^{1}$ Grupo de Investigaciones Ambientales, \\ Universidad Pontificia Bolivariana, Colombia \\ ${ }^{2}$ Grupo de Energía y Termodinámica, \\ Universidad Pontificia Bolivariana, Colombia
}

\begin{abstract}
In this work three different ways to produce $1 \mathrm{MWe}$ from biomass gasification syngas are presented. The studied pathways considered the biomass gasification in order to produce syngas able to be transformed into liquid fuels through (i) fermentation and (ii) Fischer Tropsch (FT) synthesis. Later, both liquid fuels were assumed to be powered in a spark ignition engine and in a compression ignition engine, respectively. The third pathway is (iii) the direct use of syngas in a gas-fired reciprocating engine. Syngas composition was predicted from three residual lignocellulosic biomasses (rice husk, sugarcane bagasse and coffee husk) using a stoichiometric equilibrium model. It was found that the direct use of syngas (LHV $\sim 6.72 \mathrm{MJ} / \mathrm{Nm}^{3}$ ) needs less biomass $(\sim 800 \mathrm{~kg} / \mathrm{h})$ to achieve $1 \mathrm{MWe}$ in comparison with the other two pathways. Diesel fuel from FT and ethanol from the fermentation process require around $1500 \mathrm{~kg} / \mathrm{h}$ and $2500 \mathrm{~kg} / \mathrm{h}$ of biomass respectively to achieve the same power. The FT synthesis considered the production of a synthetic liquid fuel similar to diesel fuel in terms of heating value (LHV $\sim 44 \mathrm{MJ} / \mathrm{kg}$ ), while syngas fermentation took into account the ethanol production (LHV $\sim 27 \mathrm{MJ} / \mathrm{kg}$ ). The above results, for the three different fuels, were assessed considering the thermal efficiencies of each specific internal combustion engine.

Keywords: syngas, gasification, Fischer Tropsch, syngas fermentation, internal combustion engine.
\end{abstract}




\section{Introduction}

In order to reduce dependency on fossil fuels and decrease greenhouse gases emissions, global interest in bioenergy production from indigenous renewable resources has been growing in the last years. Most research and development (R\&D) activities on bioenergy have been carried out mainly in industrialized countries and also in a few emerging countries. However, the largest growth in biomass to power and biofuels production is expected in developing countries and growing economies. Although it has wide potential in these areas, the use of bioenergy in developing countries face several challenges due to the lack of industrial experience, limited investment in R\&D and the absence of support policies [1].

Nowadays, biomass has increased its importance as a renewable source not only because in the past it has been widely used to produce heat and power, but also because of its ability to be transformed into more versatile fuels such as the liquid ones as well as different kinds of chemical feedstock. Biomass could be obtained from a variety of sources such as forest (related to silvicultural activities) and agricultural waste among others. The energetic use of these kinds of feedstock considers, besides waste valorization, a less environmental impact than their petroleum counterparts in terms of $\mathrm{CO}_{2}$ emissions [2].

Colombia, a tropical country in South America, presents special weather conditions for growing different kinds of crops (coffee, sugar cane, rice, African oil palm, etc.) as well for promoting fast vegetation regeneration. These facts imply that the energy production from biomass sources is receiving a growing attention. Zones such as Amazonas and Andes present the biggest amount of biomass with 12,777 and 1,652 million of mega grams (Mg) respectively [3]. According to the International Energy Agency, total energy production in Colombia in 2012 was 49,590 GWh where 3.94\% (1,953 GWh) was produced from solid biofuels [4].

This work evaluates three different ways to produce electrical energy by using syngas obtained from biomass gasification. The first pathway considers the syngas to be used directly in a gas-fired reciprocating engine. The second and the third routes consider the syngas transformation into liquid fuels through fermentation and Fischer Tropsch (FT) synthesis to be powered in a spark ignition engine and in a compression ignition engine, respectively. These pathways were studied from three representative lignocellulosic biomasses (rice husk, coffee husk and sugar cane bagasse) according to their production role in Colombia.

\subsection{Biomass to energy}

Energy production from biomass could follow different conversion routes. These routes could be classified into thermochemical (pyrolysis, gasification and combustion), biochemical (fermentation and digestion) and catalytic (FT synthesis) processes to produce power, heat and transportation fuels. In this work a gasification process is studied from the theoretical standpoint to produce 
syngas mainly composed by $\mathrm{CO}$ and $\mathrm{H}_{2}$. From this gaseous fuel, three different processes are assessed in order to produce $1 \mathrm{MWe}$. The three processes are described as follows: (i) direct use of syngas in a gas-fired reciprocating engine, (ii) syngas fermentation to obtain ethanol to be fuelled in a spark ignition engine, and (iii) Fischer Tropsch synthesis to produce Diesel fuel to be fuelled in a compression ignition engine.

\subsection{Internal combustion engine (ICE) fueled directly with syngas}

Syngas shows different combustion properties as compared to conventional fuels (gasoline and diesel) and therefore conventional engines need some modifications in order to run with this gaseous fuel. Nevertheless, gas-fired reciprocating engines fueled with syngas are available in the current market. Martínez et al. [5] show different issues to be considered when a syngas from biomass gasification obtained in downdraft reactors is fueled in conventional reciprocating engines. They found that low energy density of the producer gas/air mixture and the engine's volumetric efficiency are the main factors causing the power de-rating of the engine. Additionally due to the high flame speed of the producer gas/air mixture, it is necessary to retard the spark ignition time. Overall efficiencies roughly $20 \%$ were reported when the engine was fueled with $100 \%$ syngas. Performance of an internal combustion engine fueled with producer gas was also evaluated for Tsiakmakis et al. [6] but in this case, the engine was coupled with a fluidized bed reactor. The syngas obtained from three kinds of biomasses was mixed with propane and different blends ratios were used to feed the engine. Overall efficiencies between 20 and 25\% were found independently of the biomass used. The authors concluded that power derating does not exceed $10 \%$ for mixtures of $55 \% \mathrm{w} / \mathrm{w}$ syngas and $45 \% \mathrm{w} / \mathrm{w}$ propane. Other authors such as Lee et al. [7] and Raman and Ram [8] also obtained similar overall efficiencies independently of the biomass (around 20\%).

\subsection{Fischer Tropsch (FT) synthesis}

FT synthesis is a catalytic process that uses transition metals (especially $\mathrm{Co}, \mathrm{Fe}$ and $\mathrm{Ru}$ ) to convert syngas into liquid fuels [9] and operates at pressures and temperatures ranging from 20 to 40 bars and 180 to $250^{\circ} \mathrm{C}$, respectively [10]. In this process, an overall exothermic reaction take place and hydrocarbons with variable chain length are formed from $\mathrm{H}_{2} / \mathrm{CO}$ ratios near to 2.1/1 depending on the catalyst selectivity. Since syngas from biomass gasification in most cases lead to significantly lower $\mathrm{H}_{2} / \mathrm{CO}$ ratios (around of $0.7 / 1$ ), a water gas shift reaction is necessary to increase the $\mathrm{H}_{2}$ concentration in syngas [11].

Various efforts have been expended in order to develop more efficient biomass to liquid fuel processes (BTL). Hamelinck et al. [12] built a model in Aspen Plus to evaluate the influence of each parameter involved in the FT process on investment cost, electricity efficiency and resulting diesel cost. Overall efficiencies between 40 and $45 \%$ on the HHV biomass basis were found. On the other hand, Kim et al. [13] demonstrated that a downdraft gasifier is able to produce 7.8 liters of hydrocarbon liquid fuel (fractions of gasoline, kerosene 
and diesel along wax with carbon number greater than 5) from $48 \mathrm{~kg}$ of woody biomass. Diesel from FT synthesis via biomass gasification has gained special attention because it offers a clean and potentially neutral carbon liquid fuel able to be employed directly in the transportation sector. In this sense, diesel was chosen as the main product in this process.

\subsection{Syngas fermentation}

Syngas fermentation is a potential microbial pathway in which anaerobic microorganism is utilized to mediate the bio-catalytic conversion of syngas components to various useful biochemical and biofuels [14], where ethanol is the most desirable product. Syngas can be converted to ethanol using different acetogens such as "Clostridium ljungdahlii", "Clostridium ragsdalei", "Clostridium carboxidivorans" and "Clostridium autoethanogenum'. These species follow the reductive acetyl-CoA pathway for growth and production of acetic acid and ethanol from $\mathrm{CO}, \mathrm{H}_{2}$ and $\mathrm{CO}_{2}$ at $\mathrm{pH}$ range from 4.0 to 7.0 and temperatures between 37 and $40^{\circ} \mathrm{C}$ [15].

Even though syngas fermentation is a relatively new technology, it presents the advantage of high specificity to substrate, low temperature and pressure operation conditions $\left(35-40^{\circ} \mathrm{C}\right.$ and $\left.0.8-1.8 \mathrm{~atm}\right)$ and high tolerance to toxic gases [16]. $\mathrm{Xu}$ et al. [17], evaluated the impurities generated in the gasification and their effects on the microbial fermentation process. Impurities such as tar, nitric oxide and ammonia may directly affect the organism (cell toxicity, enzyme inhibition, product distribution, etc.) or indirectly affect the fermentation process by changing process conditions ( $\mathrm{pH}$, osmolarity, redox potential, etc.). Clausen and Gaddy [18], reported high ethanol concentration (approx. $48 \mathrm{~g} / 1$ after $560 \mathrm{~h}$ of fermentation process) at $\mathrm{pH}$ between 4.0 and 4.5 using Clostridium ljungdahlii in a continuous stirred tank reactor. Generally speaking, for syngas fermentation the overall efficiency in terms of feedstock conversion into liquid fuels is between $39 \%$ and $57 \%[19,20]$.

\section{Material and methods}

\subsection{Feedstock}

Three different biomasses were chosen for this study as commented above. According to the Colombian agricultural sector, rice husk, coffee husk and sugarcane bagasse are the lignocellulosic biomasses with highest potential to be transformed due to their high production rate and also because their final disposition considers a challenge from the disposal waste standpoint. Tables 1 and 2 show the Colombian production per year and the ultimate analysis of each biomass, respectively.

\subsection{Methods}

As said before, syngas from biomass gasification was studied from three different processes aiming the production of $1 \mathrm{MWe}$. Overall efficiencies of each 
Table 1: $\quad$ Biomass production-adapted from [21].

\begin{tabular}{|c|c|c|c|c|}
\hline Crop & Area (ha) & Production (t/year) & Waste & $\begin{array}{c}\text { Energy potential } \\
\text { (TJ/year) }\end{array}$ \\
\hline Sugar cane & 210,566 & $2,615,251$ & Bagasse & $41,707.2$ \\
\hline Coffee & 762,846 & 942,327 & Coffee husk & $3,338.6$ \\
\hline Rice & 455,444 & $2,463,689$ & Rice husk & $7,136.5$ \\
\hline
\end{tabular}

Table 2: $\quad$ Ultimate analysis for each biomass-adapted from [22].

\begin{tabular}{|c|c|c|c|c|c|c|c|}
\hline Biomass & C & H & N & S & O & Total & LHV (kJ/kg) \\
\hline Coffee husk & 45.06 & 6.42 & 2.53 & 0.48 & 45.51 & 100 & 16,493 \\
\hline Sugar cane Bagasse & 44.10 & 5.70 & 0.20 & 2.30 & 47.70 & 100 & 17,800 \\
\hline Rice husk & 46.22 & 6.06 & 2.58 & 0.14 & 45.00 & 100 & 17,290 \\
\hline
\end{tabular}

process were taken from the literature and both mass and energy balances to know the biomass mass flow rate needed to produce $1 \mathrm{MWe}$. A stoichiometric equilibrium model developed in EES (Engineering Equation Solver) was used to determine the final composition and the heating value of syngas obtained from each lignocellulosic biomass as will be explained later.

\subsubsection{Stoichiometric equilibrium model}

The syngas composition and hence the LHV was estimated through a stoichiometric equilibrium model explained in detail elsewhere [23]. This model assumes that all gases behave like ideal gases and all reactions took place at $1 \mathrm{~atm}$. Similarly, it is worth to point out that possible tar and solid carbon formation was neglected. The reaction temperature was the result of the energy balance assuming adiabatic conditions. Among all available models to determine syngas composition this one is reasonably precise with respect to the real composition [24]. This type of model is considered to be a useful engineering tool for evaluating the effect of fuel composition on gasification gas composition [25]. In fact, these models have been broadly and satisfactorily used to predict the chemical composition of syngas obtained in downdraft fixed bed gasifiers using different biomasses as fuel [26-28].

The overall reaction of the gasification process considered by the model is shown in equation (1). The composition of the reaction products were calculated from the mass balance of each element and from the reactions in equations (2) to (5).

$$
\begin{aligned}
& \mathrm{C}_{\mathrm{C}_{v}} \mathrm{H}_{\mathrm{H}_{v}} \mathrm{O}_{\mathrm{O}_{v}} \mathrm{~N}_{\mathrm{N}_{v}} \mathrm{~S}_{\mathrm{S}_{v}}+x_{1}\left(\mathrm{O}_{2}+3.76 \mathrm{~N}_{2}\right)+x_{2}\left(\mathrm{H}_{2} \mathrm{O}\right) \\
& \rightarrow n_{\mathrm{CO}} \mathrm{CO}+n_{\mathrm{CO}_{2}} \mathrm{CO}_{2}+n_{\mathrm{H}_{2}} \mathrm{H}_{2}+n_{\mathrm{CH}_{4}} \mathrm{CH}_{4}+n_{\mathrm{N}_{2}} \mathrm{~N}_{2} \\
& +n_{\mathrm{H}_{2} \mathrm{O}} \mathrm{H}_{2} \mathrm{O}+n_{\mathrm{H}_{2} \mathrm{~S}} \mathrm{H}_{2} \mathrm{~S}+n_{\mathrm{COS}} \mathrm{COS}+n_{\mathrm{SO}_{2}} \mathrm{SO}_{2}
\end{aligned}
$$

Homogeneous water gas-shift reaction:

$$
\mathrm{CO}+\mathrm{H}_{2} \mathrm{O} \leftrightarrow \mathrm{CO}_{2}+\mathrm{H}_{2}
$$


Heterogeneous methane production reaction (methane reaction):

$$
\mathrm{C}+2 \mathrm{H}_{2} \leftrightarrow \mathrm{CH}_{4}
$$

Sulfur-related reactions:

$$
\begin{gathered}
\mathrm{CO}+\mathrm{H}_{2} \mathrm{~S} \leftrightarrow \mathrm{COS}+\mathrm{H}_{2} \\
\mathrm{COS}+2 \mathrm{CO}_{2} \leftrightarrow 3 \mathrm{CO}+\mathrm{SO}_{2}
\end{gathered}
$$

\section{Results and discussions}

Different parameters are taken from the literature to carry out the mass and energy balances of each process in order to determine the biomass mass flow rate needed to produce the required electrical power. This information is summarized for each process as follows.

\subsection{Internal combustion engine (ICE) fueled directly with syngas}

According to literature, overall efficiencies around 20-25\% are reported. This range involves the efficiencies for the gasification process and the internal

\begin{tabular}{|c|c|c|c|c|c|c|}
\hline \multirow[b]{2}{*}{$\begin{array}{c}\eta_{\text {gasification }} \\
(\%)\end{array}$} & \multirow[b]{2}{*}{$\begin{array}{l}\eta_{\text {ICE }} \\
(\%)\end{array}$} & \multirow[b]{2}{*}{$\begin{array}{c}\eta_{\text {overall }} \\
(\%)\end{array}$} & \multicolumn{3}{|c|}{ Observation } & \multirow[b]{2}{*}{ Ref. } \\
\hline & & & $\begin{array}{l}\text { Reactor } \\
\text { technology }\end{array}$ & $\begin{array}{c}\text { Equivalent } \\
\text { ratio }\end{array}$ & $\begin{array}{c}\text { Engine } \\
\text { characteristics }\end{array}$ & \\
\hline \multirow{4}{*}{$70-75$} & \multirow{4}{*}{$29-33$} & \multirow{4}{*}{$20-25$} & $\begin{array}{l}\text { Bubbling } \\
\text { fluidized bed }\end{array}$ & 0.3 & $\begin{array}{l}\text { Single-cylinder; } \\
4 \text { stroke; spark } \\
\text { ignition engine }\end{array}$ & [6] \\
\hline & & & \multirow[b]{2}{*}{$\begin{array}{l}\text { Downdraft } \\
\text { moving bed }\end{array}$} & $\sim 0.25$ & Diesel/modified & [29] \\
\hline & & & & $\begin{array}{l}0.394 / 0.546 / \\
0.377 / 0,517\end{array}$ & $\begin{array}{l}\text { Spark ignition } \\
\text { engine }\end{array}$ & [7] \\
\hline & & & Not reported & $0.35 / 0.32$ & $\begin{array}{l}\text { Natural gas } \\
\text { engine }\end{array}$ & [8] \\
\hline
\end{tabular}
combustion engine.

Table 3: $\quad$ Performance of some ICEs fueled with syngas.

The mass flow for each biomass chosen is presented in Table 4. The production of $1 \mathrm{MWe}$ by feeding directly the syngas in a gas-fired reciprocating engine needs a biomass flow rate between 838.3 and $1,047.9 \mathrm{~kg} / \mathrm{s}$ according to

\begin{tabular}{|c|c|c|c|c|c|}
\hline Biomass & $\eta_{\text {overall }}(\%)$ & MWe & LHV (kJ/kg) & \multicolumn{2}{|c|}{$\dot{\mathbf{m}}_{\text {Biomass }}(\mathrm{kg} / \mathbf{s})$} \\
\hline Coffee husk & \multirow{3}{*}{$20-25$} & \multirow{3}{*}{1} & 16,493 & $1,091.3$ & 873.1 \\
\hline Bagasse & & & 17,800 & $1,011.2$ & 809.0 \\
\hline Rice husk & & & 17,290 & $1,041.1$ & 832.9 \\
\hline
\end{tabular}
the range of efficiencies reported.

Table 4: $\quad$ Results for mass flow of biomass using ICE. 


\subsection{Fischer Tropsch}

It is well-known that FT is a potential process to obtain liquid fuels from syngas. In this process, parameters such as the kind of catalyst as well as the $\mathrm{H}_{2} / \mathrm{CO}$ ratio play an important role in both characteristics and yield of the liquid produced. Cobalt and iron compounds are the most common catalysts used due to their low price. Table 5 summarizes some important conditions for FT synthesis as well as the specific and overall efficiencies for this process.

Table 5: $\quad$ Performance of some catalytic process fed with syngas.

\begin{tabular}{|c|c|c|c|c|c|c|c|}
\hline \multirow[b]{2}{*}{$\begin{array}{c}\begin{array}{c}\eta_{\text {gasification }} \\
(\%)\end{array} \\
\end{array}$} & \multirow[b]{2}{*}{$\begin{array}{c}\eta_{\text {process }} \\
(\%)\end{array}$} & \multirow[b]{2}{*}{$\begin{array}{l}\eta_{\text {ICE }} \\
(\%)\end{array}$} & \multirow[b]{2}{*}{$\begin{array}{c}\eta_{\text {loverall }} \\
(\%)\end{array}$} & \multicolumn{3}{|c|}{ Observations } & \multirow[b]{2}{*}{ Ref. } \\
\hline & & & & Catalyst & $\begin{array}{c}\mathrm{H}_{2} / \mathrm{CO} \\
\text { ratio } \\
\end{array}$ & $\begin{array}{c}\text { Probability } \\
(\alpha)\end{array}$ & \\
\hline \multirow{3}{*}{$70-75$} & \multirow{3}{*}{$57-67$} & \multirow{3}{*}{$30-40$} & \multirow{3}{*}{$12-20$} & Cobalt and Iron & $2.1 / 1$ & $0.8-0.9$ & {$[11]$} \\
\hline & & & & $\begin{array}{l}\text { Cobalt and } \\
\text { Ruthenium }\end{array}$ & $\begin{array}{l}\text { Decreasing } \\
\mathrm{H}_{2} / \mathrm{CO} \\
\text { ratio, } \\
\text { increase } \alpha \\
\text { and liquid } \\
\text { yield }\end{array}$ & $\begin{array}{l}\text { Should be } \\
\text { close to } 1 \text { to } \\
\text { obtain liquid } \\
\text { products }\end{array}$ & {$[12]$} \\
\hline & & & & Iron & $\begin{array}{l}<2 \text { (the } \\
\text { nearer to } \\
\text { two, the } \\
\text { higher } \\
\text { liquid yield } \\
\text { production) }\end{array}$ & Not reported & {$[30]$} \\
\hline
\end{tabular}

The mass flow of biomass required to produce the diesel fuel needed to be used in a compression ignition engine and thus generate $1 \mathrm{MWe}$ ranges between $1,047.9$ and $1,746.5 \mathrm{~kg} / \mathrm{s}$ independent of the biomass used. Table 6 shows the mass flow for each biomass.

Table 6: Results for mass flow of biomass using catalytic reactor.

\begin{tabular}{|c|c|c|c|c|c|}
\hline Biomass & $\eta_{\text {overall }}(\%)$ & MWe & LHV (kJ/kg) & \multicolumn{2}{|c|}{$\dot{\mathbf{m}}_{\text {biomass }}(\mathrm{kg} / \mathrm{s})$} \\
\hline Coffee husk & \multirow{3}{*}{$12-20$} & \multirow[t]{3}{*}{ 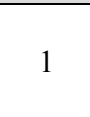 } & 16,493 & $1,818.9$ & $1,091.3$ \\
\hline Bagasse & & & 17,800 & $1,685.4$ & $1,011.2$ \\
\hline Rice husk & & & 17,290 & $1,735.1$ & $1,041.1$ \\
\hline
\end{tabular}

\subsection{Syngas fermentation}

In syngas fermentation the $\mathrm{H}_{2} / \mathrm{CO}$ ratio is not an important parameter to obtain a good performance. However, $\mathrm{pH}$ and temperature conditions have a great influence for ethanol production. Overall efficiencies which combine all gasification process, fermentation process and the spark ignition engine are reported in Table 7. 
Table 7: Performance of some fermentative process fed with syngas.

\begin{tabular}{|c|c|c|c|c|c|c|c|c|}
\hline \multirow{2}{*}{$\begin{array}{c}\eta_{\text {gasification }} \\
(\%)\end{array}$} & \multirow{2}{*}{$\begin{array}{c}\eta_{\text {process }} \\
(\%)\end{array}$} & \multirow{2}{*}{$\begin{array}{l}\eta_{\text {ICE }} \\
(\%)\end{array}$} & \multirow{2}{*}{\begin{tabular}{|c}
$\eta_{\text {loverall }}$ \\
$(\%)$
\end{tabular}} & \multicolumn{4}{|c|}{ Observations } & \multirow{2}{*}{ Ref. } \\
\hline & & & & Microorganism & Reactor & $\mathbf{T}\left({ }^{\circ} \mathrm{C}\right)$ & pH & \\
\hline \multirow{4}{*}{$70-75$} & \multirow{4}{*}{$55-76$} & \multirow{4}{*}{$37-40$} & \multirow{4}{*}{$14-23$} & $\begin{array}{c}\text { Clostridia } \\
\text { bacteria }\end{array}$ & $\begin{array}{c}\text { LanzaTech } \\
\text { Reactor }\end{array}$ & $35-42$ & $4-6$ & [20] \\
\hline & & & & $\begin{array}{l}\text { Clostridia- } \\
\text { thermophile }\end{array}$ & \multirow{2}{*}{ STR } & $55-60$ & 6 & \multirow{2}{*}[31]{} \\
\hline & & & & $\begin{array}{l}\text { Clostridia- } \\
\text { mesophile }\end{array}$ & & $30-40$ & 4.7 & \\
\hline & & & & $\begin{array}{l}\text { Clostidium } \\
\text { Ljungdahlii }\end{array}$ & CSTBR & 37 & 4.5 & [32] \\
\hline
\end{tabular}

STR: Stirred Tank Reactor; CSTBR: Continuous Stirred Tank Reactor.

In this case, an adequate environment to promote the microorganism growth must be ensured. Through this process, ethanol is produced and then a spark ignition engine is used to generate the electrical power. In accordance with the range of the overall efficiencies and the power output needed, a mass flow of biomass between 911.2 and $1,497 \mathrm{~kg} / \mathrm{s}$ is necessary depending on the lignocellulosic biomass.

Table 8: $\quad$ Results for mass flow of biomass using biochemical reactor.

\begin{tabular}{|c|c|c|c|c|c|}
\hline Biomass & $\eta_{\text {overall }}(\%)$ & MWe & LHV (kJ/kg) & \multicolumn{2}{|c|}{$\dot{\mathbf{m}}_{\text {biomass }}(\mathrm{kg} / \mathrm{s})$} \\
\hline Coffee husk & \multirow{3}{*}{$14-23$} & \multirow{3}{*}{1} & 16,493 & $1,559.1$ & 949.0 \\
\hline Bagasse & & & 17,800 & $1,444.6$ & 879.3 \\
\hline Rice husk & & & 17,290 & $1,487.2$ & 905.3 \\
\hline
\end{tabular}

Summarizing the aforementioned results, Figure 1 shows both the higher and the lower limit of mass flow rate, as a function of the lignocellulosic biomass, necessary for conducting each pathway analyzed in this work.

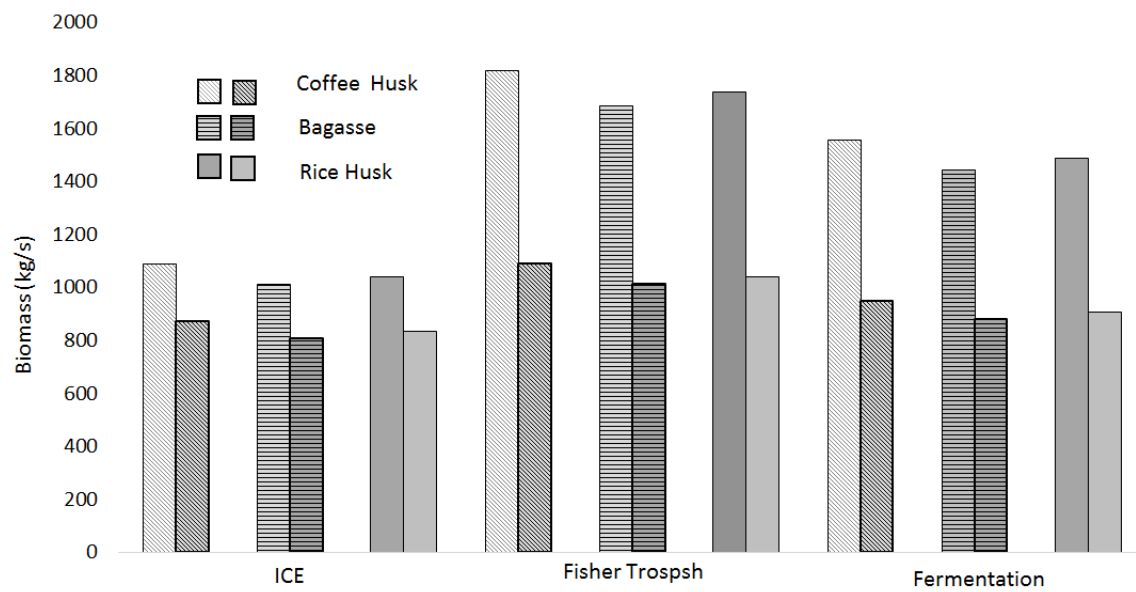

Figure 1: Mass flow rate for each process and kind biomass. 


\section{Conclusions}

In this work three processes were analyzed in order to know the mass flow rate of three different lignocellulosic biomasses to produce $1 \mathrm{MWe}$. It can be noticed that using the syngas produced by gasification process directly in a gas-fired reciprocating engine seems to be the most efficient pathway because a smaller amount of biomass is needed as compared to the other two processes in order to produce the same power output (1 MWe). However, liquid fuels obtained via FT synthesis or syngas fermentation have important advantages in terms of transportation, distribution and storage, making these processes highly attractive to be considered in the wider variety of alternative fuels that are necessary for the upcoming years. Diesel obtained from FT synthesis has similar characteristics to conventional diesel fuel in terms of heating value (LHV $44 \mathrm{MJ} / \mathrm{kg}$ ) and good combustion properties such as higher cetane number. Syngas fermentation has some advantages in conjunction with catalytic process, including higher yield production, lower energy cost, robustness with regard to $\mathrm{H}_{2} / \mathrm{CO}$ ratio and higher process efficiency.

\section{References}

[1] M. A. Gonzalez-Salazar, M. Morini, M. Pinelli, P. R. Spina, M. Venturini, M. Finkenrath, and W.-R. Poganietz, "Methodology for biomass energy potential estimation: Projections of future potential in Colombia," Renew. Energy, vol. 69, pp. 488-505, Sep. 2014.

[2] D. Yue, F. You, and S. W. Snyder, "Biomass-to-bioenergy and biofuel supply chain optimization: Overview, key issues and challenges," Comput. Chem. Eng., vol. 66, pp. 36-56, Jul. 2014.

[3] J. A. Anaya, E. Chuvieco, and A. Palacios-Orueta, "Aboveground biomass assessment in Colombia: A remote sensing approach," For. Ecol. Manage., vol. 257, no. 4, pp. 1237-1246, Feb. 2009.

[4] IEA, "Statistics," Colombia: Renewables and Waste for 2012, 2012. [Online]. Available: http://www.iea.org/.

[5] J. D. Martínez, K. Mahkamov, R. V. Andrade, and E. E. Silva Lora, "Syngas production in downdraft biomass gasifiers and its application using internal combustion engines," Renew. Energy, vol. 38, no. 1, pp. 19, Feb. 2012.

[6] S. Tsiakmakis, D. Mertzis, A. Dimaratos, Z. Toumasatos, and Z. Samaras, "Experimental study of combustion in a spark ignition engine operating with producer gas from various biomass feedstocks," Fuel, vol. 122, pp. 126-139, Apr. 2014.

[7] U. Lee, E. Balu, and J. N. Chung, "An experimental evaluation of an integrated biomass gasification and power generation system for distributed power applications," Appl. Energy, vol. 101, pp. 699-708, Jan. 2013.

[8] P. Raman and N. K. Ram, "Performance analysis of an internal combustion engine operated on producer gas, in comparison with the 
performance of the natural gas and diesel engines," Energy, vol. 63, pp. 317-333, Dec. 2013.

[9] V. R. R. Pendyala, G. Jacobs, W. Ma, J. L. S. Klettlinger, C. H. Yen, and B. H. Davis, "Fischer-Tropsch synthesis: Effect of catalyst particle (sieve) size range on activity, selectivity, and aging of a Pt promoted $\mathrm{Co} / \mathrm{Al}_{2} \mathrm{O}_{3}$ catalyst," Chem. Eng. J., vol. 249, pp. 279-284, Aug. 2014.

[10] K. Mai, T. Elder, L. H. Groom, and J. J. Spivey, "Fe-based Fischer Tropsch synthesis of biomass-derived syngas: Effect of synthesis method," Catal. Commun., vol. 65, pp. 76-80, May 2015.

[11] M. J. Tijmensen, P. C. Faaij, C. N. Hamelinck, and M. R. M. Van Hardeveld, "Exploration of the possibilities for production of Fischer Tropsch liquids and power via biomass gasification," Biomass and Bioenergy, vol. 23, no. 2, pp. 129-152, 2002.

[12] C. Hamelinck, A. Faaij, H. Denuil, and H. Boerrgter, "Production of FT transportation fuels from biomass; technical options, process analysis and optimisation, and development potential," Energy, vol. 29, no. 11, pp. 1743-1771, Sep. 2004.

[13] K. Kim, Y. Kim, C. Yang, J. Moon, B. Kim, J. Lee, U. Lee, S. Lee, J. Kim, W. Eom, S. Lee, M. Kang, and Y. Lee, "Long-term operation of biomass-to-liquid systems coupled to gasification and Fischer-Tropsch processes for biofuel production.," Bioresour. Technol., vol. 127, pp. 3919, Jan. 2013.

[14] M. Mohammadi, G. D. Najafpour, H. Younesi, P. Lahijani, M. H. Uzir, and A. R. Mohamed, "Bioconversion of synthesis gas to second generation biofuels: A review," Renew. Sustain. Energy Rev., vol. 15, no. 9, pp. 4255-4273, Dec. 2011.

[15] K. Liu, H. K. Atiyeh, B. S. Stevenson, R. S. Tanner, M. R. Wilkins, and R. L. Huhnke, "Continuous syngas fermentation for the production of ethanol, n-propanol and n-butanol.," Bioresour. Technol., vol. 151, pp. 69-77, Jan. 2014.

[16] K. Liu, H. K. Atiyeh, R. S. Tanner, M. R. Wilkins, and R. L. Huhnke, "Fermentative production of ethanol from syngas using novel moderately alkaliphilic strains of Alkalibaculum bacchi.," Bioresour. Technol., vol. 104, pp. 336-41, Jan. 2012.

[17] D. Xu, D. R. Tree, and R. S. Lewis, "The effects of syngas impurities on syngas fermentation to liquid fuels," Biomass and Bioenergy, vol. 35, no. 7, pp. 2690-2696, Jul. 2011.

[18] E. C. Clausen and J. L. Gaddy, "Ethanol from biomass by gasification/fermentation.," Prepr. Pap. - Am. Chem. Soc. Div. Fuel Chem., vol. 38, no. 3, pp. 855-861, 1993.

[19] A. Oasmaa, D. . Elliott, and S. Mu, "Quality Control in Fast Pyrolysis BioOil Production and Use," Environ. Prog., vol. 28, no. 3, pp. 404-409, 2009.

[20] J. Daniell, M. Köpke, and S. D. Simpson, Commercial biomass syngas fermentation, vol. 5, no. 12. 2012. 
[21] H. Escalante Hernández, Atlas del potencial energético de la biomasa residual en Colombia. UPME, 2010.

[22] Phyllis, "Database for Biomass and Waste," 2012.

[23] J. D. Martínez, R. Murillo, T. García, and I. Arauzo, "Thermodynamic analysis for syngas production from volatiles released in waste tire pyrolysis," Energy Convers. Manag., vol. 81, pp. 338-353, May 2014.

[24] G. Gautam, S. Adhikari, and S. Bhavnani, "Estimation of biomass synthesis gas composition using equilibrium modeling," Energy Fuel, vol. 24, pp. 2692-2698, 2010.

[25] A. Melgar, J. F. Pérez, H. Laget, and A. Horillo, "Thermochemical equilibrium modelling of a gasifying process," Energy Convers. Manag., vol. 48, no. 1, pp. 59-67, Jan. 2007.

[26] Z. A. Zainal, R. Ali, C. H. Lean, and K. N. Seetharamu, "Prediction of performance of a downdraft gasifier using equilibrium modeling for different biomass materials," Energy Convers. Manag., vol. 42, no. 12, pp. 1499-1515, Aug. 2001.

[27] C. R. Altafini, P. R. Wander, and R. M. Barreto, "Prediction of the working parameters of a wood waste gasifier through an equilibrium model," Energy Convers. Manag., vol. 44, no. 17, pp. 2763-2777, Oct. 2003.

[28] A. K. Sharma, "Equilibrium modeling of global reduction reactions for a downdraft (biomass) gasifier," Energy Convers. Manag., vol. 49, no. 4, pp. 832-842, Apr. 2008.

[29] F. V. Tinaut, A. Melgar, A. Horrillo, and A. Díez de la Rosa, "Method for predicting the performance of an internal combustion engine fuelled by producer gas and other low heating value gases," Fuel Process. Technol., vol. 87, no. 2, pp. 135-142, Jan. 2006.

[30] N. H. Leibbrandt, A. O. Aboyade, J. H. Knoetze, and J. F. Görgens, "Process efficiency of biofuel production via gasification and FischerTropsch synthesis," Fuel, vol. 109, pp. 484-492, Jul. 2013.

[31] D. W. G. and M. Schultz, "Fuel and chemical products from biomass syngas: A comparation of gas fermentation to thermochemical conversion routes," AiChe, pp. 219-224, 2012.

[32] H. Younesi, G. Najafpour, and A. R. Mohamed, "Ethanol and acetate production from synthesis gas via fermentation processes using anaerobic bacterium, Clostridium ljungdahlii," Biochem. Eng. J., vol. 27, no. 2, pp. 110-119, Dec. 2005. 